\title{
PENGARUH INFEKSI Mycobacterium tuberculosis TERHADAP NILAI LAJU ENDAP DARAH PENDERITA TUBERCULOSIS PARU DI BALAI BESAR KESEHATAN PARU MASYARAKAT MAKASSAR
}

\author{
Hasnawati \\ Jurusan Analis Kesehatan Poltekkes Kemenkes Makassar \\ hasnawati0876@gmail.com
}

\begin{abstract}
ABSTRAK
Penelitian ini berlatar belakang pada infeksi Mycobacterium tuberculosis yang dapat meningkatkan nilai Laju Endap Darah. Mycobacterium tuberculosis merupaka bakteri yang dapat menyebabkan penyakit radang parenkim paru dimana penularan bakteri tersebut melalui saluran pernafasan yang di kenal sebagai Droplet Infection. Tujuan penelitian ini yaitu untuk mengetahui adanya pengaruh infeksi Mycobacterium tuberculosis terhadap nilai laju endap darah penderita tuberculosis paru di Balai Besar Kesehatan Paru Masyarakat Makassar. Jenis penelitian ini merupakan penelitian observasi laboratorik dengan teknik pengambilan sampel secara Accidental sampling sebanyak 30 sampel. Penelitian ini di laksanakan pada tanggal 07 s.d 13 Juni 2017 di laboratorium Balai Besar kesehatan paru Masyarakat Makassar. Hasil penelitian menunjukkan bahwa dari 30 sampel yang diperiksa menunjukkan peningkatan nilai LED. Kesimpulannya adalah ada pengaruh infeksi Mycobacterium tuberculosis terhadap Nilai LED penderita TB paru Di Balai Besar Kesehatan Paru Masyarakat Makassar. Sehingga disarankan agar pemeriksaan LED dapat dilakukan pada penderita TB paru
\end{abstract}

Kata Kunci : Laju Endap Darah, Mycobacterium tuberculosis, Tuberculosis Paru

\section{PENDAHULUAN}

Tuberculosis (TB) merupakan masalah utama kesehatan masyarakat. Menurut WHO (world health organization) bahwa sepertiga penduduk dunia terinfeksi TB, setiap tahun ada Sembilan juta kasus baru dan tiga juta berujung dengan kematian, 95\% kasus TB dan 98\% kematian TB terjadi di Negara berkembang yang $75 \%$ masih dalam usia produktif. Di NegaraNegara berkembang kematian TB merupakan $25 \%$ dari seluruh kematian, yang sebenarnya dapat dicegah.

Tuberculosis paru adalah penyakit radang parenkim paru karena infeksi kuman Mycobacterium tuberculosis.
Tuberculosis paru termasuk suatu pneumonia, yaitu pneumonia yang disebabkan oleh Mycobacterium tuberculosis. Tuberculosis paru mencakup $80 \%$ dari keseluruhan penyakit tuberculosis sedangkan $20 \%$ selebihnya merupakan tuberculosis ekstrapulmonar. Diperkirakan bahwa sepertiga penduduk dunia pernah terinfeksi kuman Mycobakterium tuberculosis. (Depkes RI, 2008)

Di Indonesia kini diperkirakan ada sekitar 100.000 orang setiap tahun yang menderita tuberculosis paru. Dari perhitungan para ahli dikatakan bahwa jumlah penderita baru tiap tahunnya kira - kira setengah dari jumlah seluruh dari 
penderita yang ada artinya di Negara kita tiap tahunnya akan muncul 250.000 orang penderita baru yang dapat menularkan penyakit pada sekitarnya. Dipihak lain, menurut survey kesehatan rumah tangga yang dikerjakan oleh Departemen kesehatan di tahun 1992, tuberculosis ternyata merupakan penyebab kematian ke dua di Indonesia. Menurut survey rumah tangga sebelumnya yang dikerjakan di tahun 1986 tuberculosis menduduki peringkat ke empat dalam pola penyebab kematian di Indonesia (Widoyo, 2002).

Dalam rangka penanggulangan Tuberculosis paru antara lain diperlukan diagnosis dini sehingga dapat diobati dengan segera. Sampai sekarang diagnosis laboratorium penyakit Tuberculosis masih merupakan masalah penting di Indonesia. Diagnosis TB paru secara laboratorium dapat ditegakkan dengan ditemukannnya Basil Tahan Asam (BTA) diantaranya melalui pemeriksaan mikroskopis. (Depkes RI, 2008)

Penularan yang sering terjadi ialah melalui saluran pernafasan yang dikenal sebagai Droplet Infection, dimana basil tuberculosis dapat masuk sampai ke alveoli. Penularan semakin mudah terjadi bila ada hubungan yang erat dan lama dengan penderita tuberculosis paru aktif, salah satu bentuk penularan yang lain adalah melalui debu yang beterbangan diudara yang mengandung basil tuberculosis. (Misnadiarly, 2006).

Dalam penanggulangan tuberculosis, diagnosis ditegakkan melalui pemeriksaan darah dan dahak secara mikroskopik langsung. Cara diagnosis tuberculosis paru yang digunakan dilaboratorium klinik rumah sakit dan puskesmas adalah diagnosis bakteriologis dengan teknik mikroskopik (BTA) pada sediaan dahak. (Widoyono 2002).

Pemeriksaan laboratorium akan didapatkan data ilmiah yang bertujuan untuk digunakan dalam menghadapi masalah yang diidentifikasi melalui pemeriksaan klinis indikasi pemeriksaan laboratorium merupakan pertimbangan yang penting dalam laboratorium. Pemeriksaan laboratorium dapat digunakan untuk mendiagnosa atau memastikan suatu diagnosis awal berdasarkan riwayat penyakit dan pemeriksaan fisik (Ronald A. Sacher, 2004).

Pada umumnya setiap penderita tuberculosis pasien akan mengalami gejala - gejala umum berupa batuk berdahak lebih dari dua minggu, batuk berdarah, lemah badan, penurunan berat badan, meningkatnya suhu tubuh, keringat dimalam hari sering terjadi, berubahnya gambaran hitung leukosit darah dan meningkatnya laju endap darah (LED) (Soedarto 1995).

Nilai LED umumnya tetap dalam batas normal pada penyakit - penyakit infeksi lokal yang kecil atau infeksi akut. Sebaliknya LED menjadi sangat meninggi pada tuberculosis, infeksi kronis, demam reumatik, arthritis, dan nefritis (Depkes RI, 1989).

Mekanisme dalam pemeriksaan LED adalah fase I, tahap pengendapan (agregasi) dimana eritrosit saling menyatu atau membentu rouleaux, fase II, tahap sedimentasi dimana pengendapan eritrosit terjadi secara konstan dan berlangsung selama 30 menit dengan kecepatan maksimal. Fase III, tahap pemadatan dimana kumpulan agregat mulai melambat karena terjadi pemadatan dari eritrosit yang mengendap (Kiswari.S, 2014)).

Pembentukan rouleaux, jika rouleaux banyak terbentuk maka LED 
meningkat, dimana dalam hal hal ini di pengaruhi oleh temperatur, letak posisi pipet, fibrinogen dan globulin yang meningkat (Depkes RI. 1989).

Berdasarkan uraian di atas maka peneliti telah melakukan penelitian pengaruh infeksi Mycobacterium tuberculosis terhadap nilai Laju Endap Darah (LED) penderita tuberculosis paru Di Balai Besar Kesehatan Paru Masyarakat Makassar

\section{METODE}

Jenis penelitian yang dilakukan adalah observasi laboratorik yang bersifat deskriptif dan bertujuan untuk mengetahui adanya pengaruh infeksi Mycobacterium tuberculosis terhadap nilai Laju Endap Darah (LED) pada penderita $\mathrm{Tb}$ paru.

Penelitian ini dilaksanakan di Balai Besar Kesehatan Paru Masyarakat Makassar pada bulan Juni 2017.

Populasi dalam penelitian ini adalah semua penderita TB paru di Balai Besar Kesehatan Paru Masyarakat Makassar.
Sampel pada penelitian ini adalah penderita TB paru di Balai Besar Kesehatan Paru Masyarakat Makassar. Besar sampel yang digunakan pada penelitian ini adalah 30 sampel. Tehnik pengambilan sampel secara Accidental sampling.

\section{Pengumpulan Data}

Alat dan bahan yaitu : alat VesMatic Easy, Spoit, dan tabung penampungan sampel, kapas alcohol $70 \%$ dan sampel darah EDTA. Pemeriksaan LED dilakukan dengan alat Vesmatic.

Data penelitian yang didapatkan dari hasil pemeriksaan Laju Endap Darah (LED) pada penderita tuberculosis paru di Balai Besar Kesehatan Paru Masyarakat Makassar diolah secara deskriptif.

\section{HASIL}

Penelitian yang dilaksanakan di Laboratorium Kesehatan Balai Besar Kesehatan Paru Masyarakat Makassar, diperoleh hasil penelitian sebagai berikut :

Table 1. Hasil pemeriksaan LED dan BTA terhadap penderita Tuberculosis paru

\begin{tabular}{|c|c|c|c|c|c|}
\hline No & \multicolumn{2}{|c|}{ Hasil Pemeriksaan } & No & \multicolumn{2}{c|}{ Hasil Pemeriksaan } \\
\hline & BTA & LED/ mm/jam & & BTA & LED/ mm/jam \\
\hline 1. & +1 & 48 & 16. & +2 & 70 \\
\hline 2. & +1 & 50 & 17. & +2 & 70 \\
\hline 3. & +1 & 42 & 18. & +2 & 68 \\
\hline 4. & +1 & 40 & 19. & +2 & 74 \\
\hline 5. & +1 & 42 & 20. & +2 & 72 \\
\hline 6. & +1 & 54 & 21. & +2 & 76 \\
\hline 7. & +1 & 54 & 22. & +2 & 72 \\
\hline 8. & +1 & 48 & 23. & +2 & 68 \\
\hline 9. & +1 & 52 & 24. & +2 & 76 \\
\hline 10. & +1 & 55 & 25. & +3 & 98 \\
\hline 11. & +2 & 62 & 26. & +3 & 101 \\
\hline 12. & +2 & 68 & 27. & +3 & 109 \\
\hline 13. & +2 & 64 & 28. & +3 & 120 \\
\hline
\end{tabular}




\begin{tabular}{|c|c|c|c|c|c|}
\hline 14. & +2 & 70 & 29 & +3 & 118 \\
\hline 15. & +2 & 68 & 30. & +3 & 106 \\
\hline
\end{tabular}

Data primer 2017

Berdasarkan data pada tabel 1, menunjukkan adanya pengaruh infeksi Mycobacterium tuberculosis terhadap nilai Laju Endap Darah (LED) di Balai Besar Kesehatan Paru Masyarakat Makassar, terdiri dari 30 orang pasien denga BTA positif, terdiri dari 10 orang pasien dengan BTA $+1,14$ orang pasien dengan $\mathrm{BTA}+2$ dan 6 orang pasien BTA +3 ,
LED meningkat berdasarkan derajat gradasi (tingkat posif) yang dialami pasien tersebut semakin tinggi tingkat positif BTA nya maka nilai LED nya semakin tinggi.

Berdasarkan analisis uji regresi (pengaruh) infeksi Mycobacterium tuberculosis terhadap terhadap nilai LED pada penderita TB paru dapat dilihat pada tabel di bawah ini

Table 2 Hasil uji regresi (pengaruh) infeksi Mycobacterium tuberculosis terhadap terhadap nilai LED pada penderita TB paru

\begin{tabular}{|c|c|c|c|c|c|c|}
\hline \multirow{2}{*}{ Model } & \multicolumn{2}{|c|}{$\begin{array}{c}\text { Unstandardized } \\
\text { Coefficients }\end{array}$} & $\begin{array}{c}\text { Unstandardized } \\
\text { Coefficients }\end{array}$ & \multirow{2}{*}{$\mathrm{T}$} & \multirow{2}{*}{ Sig } \\
\cline { 3 - 5 } & B & Std Error & Beta & & \\
\hline \multirow{2}{*}{1} & Constant & 16.310 & 3.638 & & 4.483 & 000 \\
\cline { 2 - 5 } & Gradasi BTA & 29.030 & 1.819 & 949 & 15.959 & 000 \\
\hline
\end{tabular}

Tabel 2 adalah hasil olahan data dari uji regresi yang menunjukkan adanya pengaruh infeksi Mycobacterium tuberculosis terhadap nilai LED karena nilai $\mathrm{P}<0,05$ sedangkan hasil dari data tersebut adalah 0,00 ini menunjukkan bahwa $0,00<0,05$ maka Ho ditolah berarti infeksi tersebut mempengaruhi nilai LED.

\section{PEMBAHASAN}

Pada penelitian ini, berdasarkan nilai Laju Endap Darah yang telah diperiksa sebanyak 30 sampel dengan BTA positif (+) di Laboratorium Balai Besar Kesehatan Paru Masyarakat Makassar mengalami peningkatan nilai LED berdasarkan derajat positif hasil BTA-nya, walaupun pada penelitian ini ditemukan peningkatan nilai LED pada pasien TB paru. Tetapi peningkatan LED tidak selamanya ditemukan pada penderita TB paru saja, Namun pada dasar peningkatan nilai LED dapat terjadi pada penyakit - penyakit infeksi lain, oleh sebab itu nilai LED tidak digunakan sebagai penegak diagnosa tetapi digunakan sebagai penunjang diagnosa.

LED merupakan respon terhadap trauma, inflamasi atau kehamilan yang ditandai dengan peningkatan kadar globulin dan fibrinogen, peningkatan LED terjadi pula apabila inflamasi kronik menjadi akut. Pemeriksaan LED secara rutin dapat menunjukkan perkembangan apakah penyakit diderita mengalami proses penyembuhan misalnya pada penyakit TB paru dan demam rematik. LED adalah reaksi non sfesifik dari tubuh, dikatakan 
demikian karena LED biasa meninggi pada penyakit-penyakit atau keadaan phatologis apa saja. LED biasanya tetap dalam batas normal pada penyakit-penyakit appendiatur infeksi setempat yang kecil, misalnya appendiatur akut dalam fase infeksi pada selaput lendir dengan sedikit reaksi radang (Afyt, 2011).

LED adalah salah satu pemeriksaan darah rutin yang menggunakan sampel darah yang diperiksan dalam suatu alat tertentu yang dinyatakan dalam $\mathrm{mm} / \mathrm{jam}$, yang bertujuan untuk mendeteksi suatu proses peradangan, infeksi, sebagai sarana pemantauan keberhasilan terapi dan perjalan penyakit terutama penyakit kronis misalnya arthritis rheumatoid dan tuberculosis. Secara umum, saat penyakit radang atau infeksi tersebut makin bertambah parah maka nilai LED semakin meningkat, sebaliknya pada saat penyakit radang atau infeksi mulai membaik perlahan-lahan LED akan menurun. (Depker RI, 1989).

Pada penelitian ini didapatkan nilai LED yang amat meningkat pada semua sampel darah berdasarkan derajat gradasi BTA-nya. Semakin tinggi derajat gradasi BTA-nya maka semakin tinggi pula nilai LED-nya karena di sebabkan oleh beratnya infeksi yang diderita oleh pasien tersebut.

Hal ini dapat kita lihat pada tabel 1 dimana nilai LED dipengaruhi oleh beratnya infeksi Mycobacterium tuberculosis dengan nilai LED ratarata di atas normal, meningkat sesuai dengan derajat gradasi BTA dari pasien tersebut, dimana nilai LED dari sampel BTA +2 lebih tinggi dari nilai LED dengan BTA +1 begitupun dengan sampel BTA +3 lebih tinggi dari nilai LED dengan BTA +2. Peningkatan LED dapat di pengaruhi oleh beberapa faktor di antaranya adalah faktor eritrosit, alat, suhu, tempat dan tehnik pemeriksaan LED.

Nilai LED umumnya tetap dalam batas normal pada penyakit penyakit infeksi lokal yang kecil atau infeksi akut. Sebaliknya LED menjadi sangat meninggi pada tuberculosis, infeksi kronis, demam reumatik, arthritis, dan nefritis (Depkes RI, 1989).

Mekanisme dalam pemeriksaan LED adalah fase I, tahap pengendapan (agregasi) dimana eritrosit saling menyatu atau membentu rouleaux, fase II, tahap sedimentasi dimana pengendapan eritrosit terjadi secara konstan dan berlangsung selama 30 menit dengan kecepatan maksimal. Fase III, tahap pemadatan dimana kumpulan agregat mulai melambat karena terjadi pemadatan dari eritrosit yang mengendap (Bakta. M, 2006)

Perubahan konsentrasi kandungan protein plasma seperti fibrinogen dan globulin yang menyertai sebagian besar infeksi akut dan kronis cenderung akan meningkatkan pembentukan rouleaux. Oleh karena itu, peningktan fibrinogen disebabkan oleh kerusakan jaringan seperti tuberculosis dan infeksi kronis lainnya akan menyebabkan peningkatan LED.(Kalma, Bakhri.S, dkk, 2015)

Pembentukan rouleaux di mana sel darah merah saling berdekatan seperti tumpukan koin, jika rouleaux banyak terbentuk maka LED meningkat, dimana dalam hal hal ini di pengaruhi oleh temperatur, letak posisi pipet, fibrinogen dan globulin yang meningkat (Depkes RI. 1989). 


\section{KESIMPULAN}

Berdasarkan hasil penelitian tentang Pengarun infeksi Mycobacterium tuberculosis terhadap nilai Laju Endap Darah (LED) di Balai Besar Kesehatan Paru Masyarakat Makassar terdapat 30 sampel dengan BTA positif (+) mengalami peningkatan nilai Laju Endap Darah (LED), maka dapat disimpulkah bahwa ada pengaruh infeksi Mycobacterium tuberculosis terhadap nilai LED.

\section{SARAN}

1. Disarankan kepada masyarakat agar lebih waspada terhadap penyakit tuberculosis paru.

2. Hendaknya pemeriksaan LED dapat di lakukan pada penderita TB paru.

3. Disarankan untuk pasien penderita TB paru agar meminum obat secara teratur dan pola hidup yang sehat.

4. Dan untuk calon peneliti yang ingin melanjutkan penelitian agar meneliti tentang perbandingan nilai LED terhadap pasien TB paru yang teratur dan tidak teratur mi num obat.

\section{DAFTAR PUSTAKA}

Afyt,2011.http://afyt.independent.blo gspot.com/demamthypoid.html/makna LED dalam klinik, diakse pada 17 Maret 2017.

Bakta, M.2006. Hematologi Klinik Ringkas. Jakarta : Buku Kedokteran. EGC

Depkes RI. 1989. Hematologi. Jakarta Depkes RI.
Depkes RI. 2008. Pedoman Nasional Pemberantasan dan Penanggulangan Tuberkulosis; Badan Litbangkes. Jakarta

Kalma, Bakhri. S, Naim.N, Umar B, Hurustiaty. 2015, Plebotomi Terapan. Poltekkes Kemenkes RI.

Kiswari Rukman, 2014. Hematologi dan Transfusi, Jakarta: CV Trans Info Medika

Misnadiarly. 2006. Tuberculosis Dan Mikobakterium Atipik.Jakarta: Dian Rakyat.

Ronald AS dan Richard AM. 2004. Tinjauan Klinis Hasil Pemeriksaan Laboratorium Edisi II. Ahli Bahasa: Brahm U. Pendit dan Dewi Wulandari. EGC; Jakarta

Soedarto. 1995. Nematoda Dalam Helmintologi Kedokteran. Jakarta. Gaya Baru.

Widoyono. 2002, Epidemiologi Penularan, Pencegahan dan Pemberantasan TBC. 